\title{
Revealing the Potency of Citrus and Galangal Constituents to Halt SARS-CoV-2 Infection
}

\author{
Rohmad Yudi Utomo ${ }^{1,2}$, Muthi' Ikawati ${ }^{1,3}$, Edy Meiyanto ${ }^{1,3, *}$ \\ ${ }^{1}$ Cancer Chemoprevention Research Center, Faculty of Pharmacy, Universitas Gadjah Mada (UGM), \\ Sekip Utara, Yogyakarta 55281, Indonesia \\ ${ }^{2}$ Medicinal Chemistry Laboratory, Department of Pharmaceutical Chemistry, Faculty of Pharmacy, \\ UGM, Sekip Utara, Yogyakarta 55281, Indonesia \\ ${ }^{3}$ Macromolecular Engineering Laboratory, Department of Pharmaceutical Chemistry, Faculty of \\ Pharmacy UGM, Sekip Utara, Yogyakarta 55281, Indonesia
}

*Corresponding author: edy_meiyanto@ugm.ac.id

ORCID:

Edy Meiyanto: 0000-0002-0886-6322

Rohmad Yudi Utomo: 0000-0003-4803-9417

Muthi' Ikawati: 0000-0002-5968-0130

\begin{abstract}
COVID-19 pandemic is a serious problem in the world today. The SARS-CoV-2 virus that causes COVID-19 has important proteins used for its infection and development, namely the protease and spike glycoprotein. The RBD (Receptor Binding Domain) of spike glycoprotein (RBD-S) can bind to the ACE2 (Angiotensin Converting Enzyme-2) receptor at the protease domain (PD) (PD-ACE2) of the host cell, thereby leading to a viral infection. This study aims to reveal the potential of compounds contained in Curcuma sp., Citrus sp., Alpinia galanga, and Caesalpinia sappan as anti SARS-CoV-2 through its binding to 3 protein receptors. The study was conducted by molecular docking using the MOE 2010 program (licensed from Faculty of Pharmacy UGM, Indonesia). The selected protein targets are RBDS (PDB ID:6LXT), PD-ACE2 (PDB ID: 6VW1), and SARS-CoV-2 protease (PDB ID:6LU7). The affinities of bonds formed is represented as a docking score. The results show that hesperidin, one of the compounds in Citrus sp., has the lowest docking score for all three protein receptors representing the highest affinity to bind the receptors. Moreover, all of the citrus flavonoids possess good affinity to the respected receptors as well as curcumin, brazilin, and galangin, indicating that those compounds perform inhibitory potential for the viral infection and replication. In general, the results of this study indicate that Citrus $s p$. exhibit the best potential as an inhibitor to the development of the SARS-CoV2 , followed by galangal, sappan wood, and Curcuma sp. that can be consumed in daily life as prophylaxis of COVID-19.
\end{abstract}

Keywords: SARS-CoV-2; Citrus sp., Galangal, Curcuma sp., Sappan wood

\section{Introduction}

The new emerging coronavirus, SARS-CoV-2, is becoming outbreaks in entire the world, spreading progressively across the continent of Asia, Europe, Middle East, Africa, and America covering more than 100 countries (as reported in WHO website www.who.int; accessed on March 10, 2010; Roser \& Ritchie, 2020). The endemic of this virus invites the challenge rapidly to find the drug in concordance with the finding of molecular characteristic of the virus. Along with the effort of the respected researchers, we put the credit to some researchers who find the structure characteristic of spike glycoprotein that plays an important role of the virus infection (Chan et al., 2020; Chen \& Du, 2020; Wrapp et al., 2020). This glycoprotein of SARS-CoV-2 exhibits little changes in the primary structure compared to the beta coronavirus, SARS-CoV, due to the mutation, providing a suitable target candidate of the new drugs (Lu et al., 2020; Xia et al., 2020).

Spike glycoprotein of SARS-CoV-2 contains Receptor Binding Domain (RBD) that recognize the target receptor leading to the splicing of the trimeric spike protein into s1 and s2 that facilitate membrane fusion and virus infection occurs through endocytosis (Yan et al., 2020). The receptor angiotensinconverting enzyme 2 (ACE2) is a preferable receptor for SARS-CoV-2 spike glycoprotein than that of spike glycoprotein of SARS-CoV due to the changes of some amino acid residues at the aa359-541, making it more suitable to bind the receptor at the "up" position (Peng et al., 2020; Wan et al., 2020; 
Wrapp et al., 2020). Therefore, the RBD of spike glycoprotein is a preferable candidate for drug target to inhibit the initiation process of virus infection. Noted that there are many compounds have been treated to RBD spike glycoprotein (Li \& De Clercq, 2020) or under molecular docking modelling as screening for drug candidates. However, the result showed a limited candidate to be the prospected drugs due to the side effect threat (Smith \& Smith, 2020; Wang, 2020; Senathilake et al., 2020).

Despite the spike glycoprotein, ACE2 is the other suitable candidate for drug target to prevent virus infection. The drug candidates may target on the spike binding site that already elucidated and simulated to bind with RBD-spike glycoprotein (Xu et al., 2020a; Yan et el., 2020). The ACE2 ligand binding side is recognized as protease domain (PD) that playing role in the cleavage of the trimeric structure of spike glycoprotein as the important step in virus infection (Xu et al., 2020b; Zhang et al., 2020; Yan et al., 2020). Therefore, the inhibitory effect of some compounds to this receptor suggest to give protection of the virus recognition.

Protease inhibitors is also suggested to be the good drug candidate to halt the virus life cycle (Qamar et al., 2020; Haider et al., 2020). Beta coronavirus utilizes protease to cleave the structural protein needed during viral formation in the host cells. The protease inhibitors have been developed to stop the spreading of viruses that cause diseases such as HIV-AIDS, MERS, and SARS (Zumla et al., 2020). Many proven drugs have been also screened with the promising result to overcome SARS-CoV-2 as drug repurposing, such as lopinavir (HIV-AIDS drug) that is continuing in clinical study (Harrison, 2020; Wang, 2020; Senathilake et al., 2020). Recently, the study on finding the best protease inhibitor for SARS-CoV-2 treatment is getting more extensive by in silico model using the crystal structure of protease domain-inhibitor complex (Chang et al., 2020; Zhavoronkov et al., 2020). This in silico approach is still challenging in order to find more precise candidates effectively with minimal adverse effect.

Exploring new medicines for emerging and rapidly spreading diseases such as SARS-CoV-2 could be carried out through drug repurposing strategy to bypass the pre-clinical steps that usually require laborious works and resources. In addition, we also need to consider developing agents which in the future could be more easily utilized by the people. For this purpose, exploration of natural resources that are often used by the people is the best choice. Here, we propose some common compounds from natural products that already known to be consumed in daily life as spices or fruits. Namely curcuminoids, the major compounds of Curcuma sp., some methoxy flavonoids, the main compounds of Citrus sp., phenolic compounds from Caesalpinia sappan (sappan wood), and phenylpropanoid compounds from Alpinia galanga (galangal) to be docked against 3 target proteins, RBD-S, PD-ACE2, and SARS-CoV-2 protease. Hopefully, this result can be used as reference in developing new drug candidates and virus prevention in daily consumption without any side effect.

\section{Methods}

Molecular docking study was chosen to be the tools for screening the binding affinity of several natural products on SARS-CoV-2 marker protein, RBD-S, PD-ACE2, and SARS-cov-2 protease. All computational simulation was conducted on Windows 10 Operating System, Intel Core i5-7th Gen as a processor with 4 GB of RAM. Molecular docking study including docking simulation, RMSD calculation, and visualization of binding interaction was performed using MOE 2010 (Licensed from Faculty of Pharmacy UGM). The model of RBD-S used reported crystal structure with PDB ID 6VSB due to the information of. prefusion spike glycoprotein structure containing single receptor-binding domain. The PDB ID 6VW1 was used as the model of PD-ACE2 in complex with RBD of SARS-CoV-2. For the crystal structure of SARS-CoV-2 protease, PDB ID 6 LU7 was used which informed the structure of protease domain in complex with protease inhibitor. The default settings were used as long as no further explanation. The chemical structure of all chemical compounds were obtained from drawn in Chemdraw software then subjected to conformational search and energy minimization in MOE. The docking simulation setting used London dG and Triangle matcher as score function and placement setting method. Forcefield method was used to refine the docking results from 30 retain setting. Results of the molecular docking described the affinity represented by docking score and binding interaction of each compound on the protein target.

\section{Results and Discussion}

Among the herbal medicine that commonly used in relieving diseases we choose 4 species as the source for active constituents to be examined as its potential as anti SARS-CoV-2, namely Curcuma 
$s p$. ., Citrus sp., Caesalpinia sappan, and Alpinia galanga. We used several representative compounds of each plant which are known to have pharmacological benefits (Figure 1). These plants are also believed to contribute for health and immune system among Asian people in relation to those of the active constituents (Meiyanto \& Larasati, 2019).

A<smiles>N=C(N)c1ccc2cc(OC(=O)c3ccc(N=C(N)N)cc3)ccc2c1</smiles><smiles>Cc1cccc(C)c1OCC(=O)N[C@@H](Cc1ccccc1)C[C@@H](O)Cc1ccccc1CNC(=O)C(C(C)C)N1CCNC1=O</smiles>

B<smiles>C=Cc1ccc(OC(C)=O)cc1</smiles><smiles>O=C1Oc2cc(O)cc(O)c2C(c2ccccc2)C1O</smiles>

C<smiles>COc1cc(/C=C/C(=O)CC(=O)C(=O)CC=Cc2ccc(O)c(O)c2)ccc1O</smiles>

D

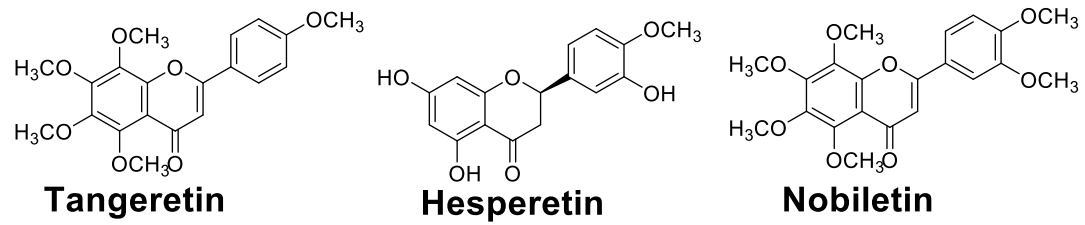

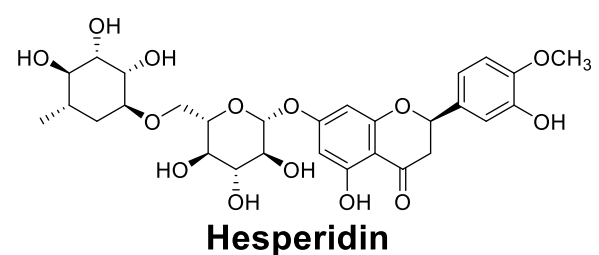<smiles>N#[W]c1cc(O)cc2c1OC(c1ccc(O)cc1)CC2O</smiles>

$\mathbf{E}$

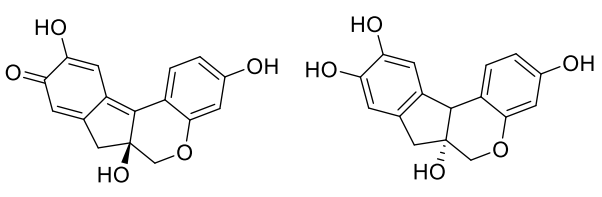

Brazilein

Brazilin

Figure 1. Chemical compounds used for the molecular docking screening. Current drug for SARS-CoV-2 therapy (A). Natural compound contained in Alpinia galanga (B). Natural compound contained in Curcuma $s p$.(C). Natural compound contained in Citrus sp. (D). Natural compound contained in Caesalpinia sappan (E). ACA: Aceto Cavicol Acetate; DMC: Desmethylcurcumin; BDMC: Bisdesmethylcurcumin

We used molecular docking with 3 target receptors; SARS-CoV-2 protease (PDB:6LU7), Spike glycoprotein-RBD (PDB:6LXT), and PD-ACE2 (PDB:6VW1); that are believed to contribute in virus infection in comparation with the respected known ligand or drugs as references. The result showed that several compounds could bind finely to the target receptors at the expected sides (Figure 2.). They gave variation of the binding energies $\Delta-G$ (Gibbs energy) represented by the docking scores among those of the compounds and those of the receptors (Table 1). Interestingly, we found that citrus and galangal compounds performed superior binding affinities to each receptor compared to those of the compounds of Curcuma sp. and sappan wood. These higher binding affinities of those of compounds could be represent significantly of its stronger inhibitory activities to the viral infection. 
A

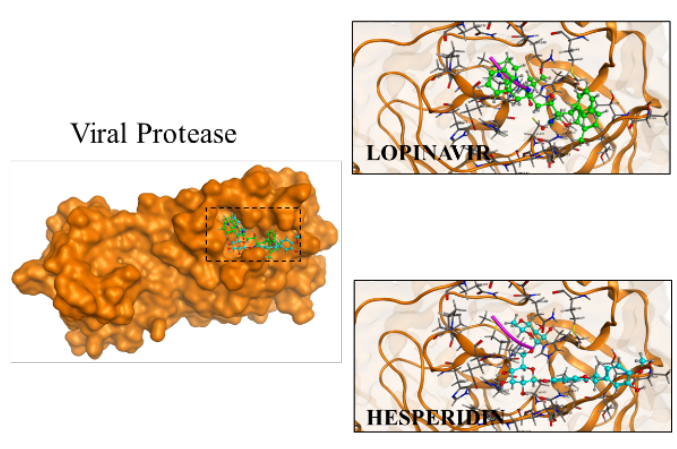

B

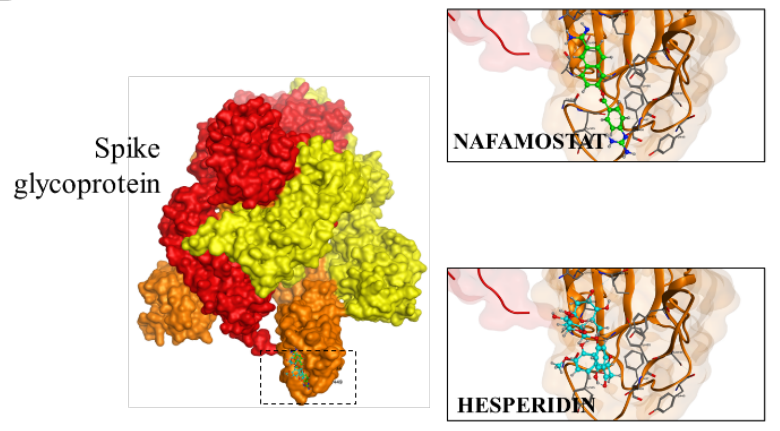

C

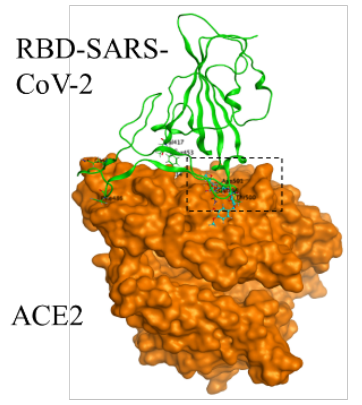

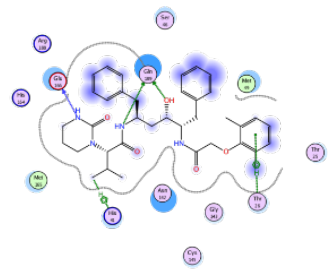

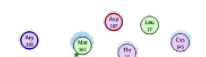

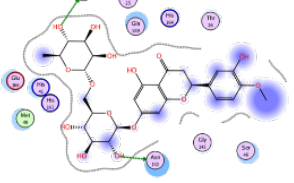

(:)
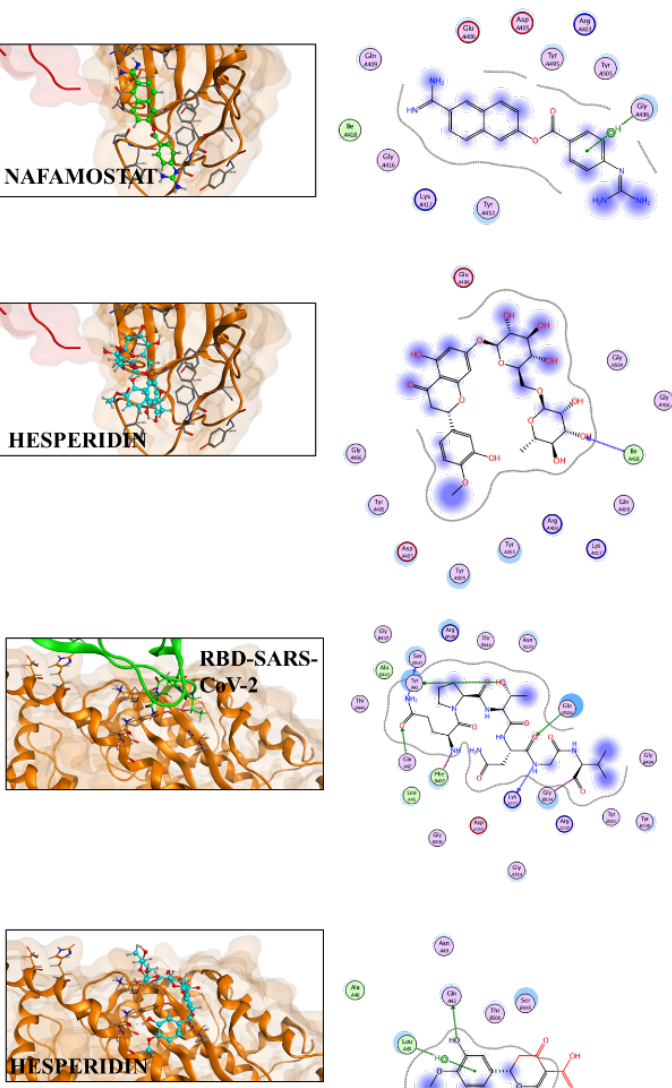

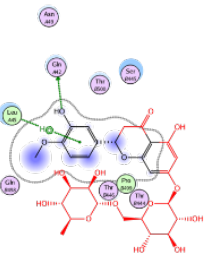

Figure 2. Binding interaction profile of hesperidin compared to lopinavir, nafamostat, and RBD of SARS-CoV-2 on protease domain of SARS-CoV-2 (A), Spike glycoprotein (B), and RBD-ACE2 complex (C).

Among the citrus flavonoids, hesperidin exhibited lowest energy binding with docking score of -13.51, 9.61, and -9.50 to the respected receptor of SARS-CoV-2 protease (6LU7), Spike glycoprotein-RBD (6LXT), and PD-ACE2 (6VW1) (Table 1). The docking score of hesperidin to SARS-CoV-2 protease showed less than lopinavir, the repurposing drug that being conducted in clinical trial for COVID-19. This finding suggest that hesperidin performs better interaction to the SARS-CoV-2 protease compared to lopinavir. Besides, hesperidin also showed better interaction to Spike-RBD compared to nafamostat, a reference compound for RBD-S binding, bringing us to consider whether hesperidin could be the new challenge for COVID-19 targeted on triple essential receptors to abrogate virus infection and replication. 
Table 1. Docking score of natural compounds towards several potential binding domain of SARS-CoV-2

\begin{tabular}{|c|c|c|c|c|}
\hline \multirow[b]{2}{*}{ Plant source } & \multirow{2}{*}{ Ligand } & \multicolumn{3}{|c|}{ Energy Gibbs (kcal/mol) } \\
\hline & & $\begin{array}{l}\text { Protease Domain } \\
\text { (6LU7) }\end{array}$ & $\begin{array}{c}\text { Spike Glycoprotein } \\
\text { (6LXT) }\end{array}$ & $\begin{array}{l}\text { RBD-ACE2 } \\
\text { (6VW1) }\end{array}$ \\
\hline- & Lopinavir & -11.62 & - & - \\
\hline- & Nafamostat & - & -7.17 & - \\
\hline \multirow{3}{*}{ Curcuma sp. } & Curcumin & -11.82 & -8.39 & -9.04 \\
\hline & DMC & -11.21 & -6.41 & -8.04 \\
\hline & BDMC & -11.51 & -8.64 & -7.48 \\
\hline \multirow{5}{*}{ Citrus sp. } & Tangeretin & -10.55 & -8.18 & -6.51 \\
\hline & Hesperetin & -12.36 & -9.08 & -6.71 \\
\hline & Hesperidin & -13.51 & -9.61 & -9.50 \\
\hline & Nobiletin & -10.38 & -7.76 & -7.88 \\
\hline & Naringenin & -12.44 & -7.40 & -7.69 \\
\hline \multirow{2}{*}{$\begin{array}{c}\text { Caesalpinia } \\
\text { sappan }\end{array}$} & Brazilein & -10.52 & -7.56 & -7.43 \\
\hline & Brazilin & -12.36 & -7.50 & -7.49 \\
\hline \multirow{2}{*}{ Alpinia galanga } & Galangin & -12.96 & -7.89 & -7.60 \\
\hline & $\mathrm{ACA}$ & -9.94 & -6.05 & -6.16 \\
\hline
\end{tabular}

Our molecular modelling also demonstrated that brazilin, a compound found in sappan wood, and galangin, a phenylprophane from galangal, bind to the three receptors with lower energy compared to the respected reference compounds. These finding indicated that both compounds possess better binding interaction and may inhibit the initial virus infection to the host cell. Moreover, we also noted that curcumin performed better interaction to the receptors. Noted that the docking scores of all the interaction models are still lower than that of hesperidin did, it still could be considered to have comparable effect of those interaction models. We may include those of compounds as candidates for further development as anti COVID-19.

All these data represent the potential inhibitory effect of Citrus sp., Curcuma sp., C. sappan, and $A$. galanga on SARS-CoV-2 infection and development that may be addressed for treatment and prevention of COVID-19. Based on the docking scores of the constituents, Citrus sp. showed the best potency, followed by A. galanga, sappan wood, and Curcuma sp. Noted for Curcuma sp. and sappan wood which are the main ingredients of most Indonesian traditional medicine "jamu" formulas, it is commonly believed to contribute in maintaining health condition due to its antioxidant activities of their constituents, such as curcumin in curcuma rhizome and brazilin in sappan wood (Meiyanto \& Larasati, 2019). People usually consume these herbs in various drinking herbal formulas. This finding supports the use of those medicinal plants for preventive or prophylaxis treatment against beta corona virus infection, including SARS-CoV-2. The same antiviral potency also performed by galangal which mainly contain galangin. Galangal has been used as spices for several food and exhibit pharmacological benefit as anti-ageing (Ahlina et al., 2020). This finding gives us to the additional benefit of this herb for antiviral.

Citrus sp. could be addressed as the best herb to be promoted to combat beta coronavirus, included SARS-CoV-2, in the forms of therapeutical or prophylaxis agents. Despite hesperidin, Citrus $s p$. contains several methoxy flavonoids, such as hesperetin, tangeretin, naringenin, and nobiletin which perform low binding energy (comparable with the reference ligands, lopinavir and nafamostat) to the three essential receptors. These low binding energies allowing those compounds to interact tightly to the target proteins. These interactions will contribute to the inhibitory effect against virus infection and replication. Those methoxy flavonoids exist in the whole fruit and more abundant in the peel in most of Citrus sp. types (Nogata et al., 2006) allowing us to easily access to the sources of compounds. In addition, those main compounds of Citrus sp. exhibit antiviral activities on several types of viruses with 
several mechanisms (Table 2). These findings seem to be in line with and support for the findings of its mechanism of action as an antiviral. Since, citrus fruit is a nontoxic material, it could be prepared as a food or mixed with other herbal medicines as "jamu". Taken together, Citrus sp. and galangal can be used as agents to overcome the impact of the coronavirus in a form that is easily consumed so that people can do it without special assistance.

Table 2. Antiviral activity of citrus flavonoid and other natural flavonoids

\begin{tabular}{|c|c|c|c|}
\hline Compound & Virus & Activity & Reference \\
\hline \multicolumn{4}{|c|}{ Citrus flavonoid } \\
\hline Hesperidin & Influenza A virus (IAV) & Inhibits viral replication & $\begin{array}{l}\text { Dong et al., } \\
2014\end{array}$ \\
\hline $\begin{array}{l}\text { Glucosyl } \\
\text { hesperidin }\end{array}$ & IAV & Reduces IAV replication & $\begin{array}{l}\text { Saha et al., } \\
2009\end{array}$ \\
\hline \multirow[t]{2}{*}{ Hesperetin } & $\begin{array}{l}\text { Severe acute respiratory } \\
\text { syndrome-coronavirus-2 } \\
\text { (SARS-CoV-2) }\end{array}$ & Binds to ACE2 receptor (in silico) & $\begin{array}{l}\text { Chen \& Du, } \\
2020\end{array}$ \\
\hline & SARS-CoV & $\begin{array}{l}\text { Inhibits cleavage activity of 3C-like } \\
\text { protease }\end{array}$ & Lin et al., 2005 \\
\hline \multirow[t]{2}{*}{ Naringenin } & $\begin{array}{l}\text { Dengue virus (DENV) } \\
\text { serotypes } 1-4\end{array}$ & Inhibits virus infection and replication & $\begin{array}{l}\text { Frabasile et al., } \\
2017\end{array}$ \\
\hline & Hepatitis $\mathrm{C}$ virus (HCV & $\begin{array}{l}\text { Reduces HCV secretion in infected } \\
\text { cells in vitro and in vivo }\end{array}$ & $\begin{array}{l}\text { Rev. in Salehi } \\
\text { et al., } 2019\end{array}$ \\
\hline \multirow[t]{2}{*}{ Nobiletin } & Hepatitis B virus (HBV) & $\begin{array}{l}\text { Inhibits HBsAg production and HBV } \\
\text { replication in vitro dan in vivo }\end{array}$ & Hu et al., 2020 \\
\hline & Chikungunya virus (CHIKV) & $\begin{array}{l}\text { Suppresses virus-induced death and } \\
\text { viral production and inhibits CHIKV } \\
\text { infection }\end{array}$ & Lin et al., 2017 \\
\hline \multirow[t]{3}{*}{ Tangeretin } & $\begin{array}{l}\text { Human respiratory syncytial } \\
\text { virus (RSV) }\end{array}$ & Inhibits RSV replication in vivo & Xu et al., 2015 \\
\hline & $\begin{array}{l}\text { Vesicular stomatitis virus } \\
\text { (VSV) }\end{array}$ & Relieves lung inflammation & \\
\hline & $\begin{array}{l}\text { Arenavirus Lassa virus } \\
\text { (LASV) }\end{array}$ & Blocks viral fusion & $\begin{array}{l}\text { Tang et al., } \\
2018\end{array}$ \\
\hline \multicolumn{4}{|c|}{ Other natural occurring compounds } \\
\hline Baicalin & SARS-CoV-2 & Binds to ACE2 receptor (in silico) & $\begin{array}{l}\text { Chen \& Du, } \\
2020\end{array}$ \\
\hline Scutellarin & SARS-CoV-2 & Binds to ACE2 receptor (in silico) & $\begin{array}{l}\text { Chen \& Du, } \\
2020\end{array}$ \\
\hline Glycyrrhizin & SARS-CoV-2 & Binds to ACE2 receptor (in silico) & $\begin{array}{l}\text { Chen \& Du, } \\
2020\end{array}$ \\
\hline Herbacetin & SARS-CoV & $\begin{array}{l}\text { Binds to SARS-CoV 3CLpro (in silico) } \\
\text { and inhibits its activity (in vitro) }\end{array}$ & Jo et al., 2020 \\
\hline Rhoifolin & SARS-CoV & Binds to SARS-CoV 3CLpro (in silico) & Jo et al., 2020 \\
\hline Pectolinarin & SARS-CoV & Binds to SARS-CoV 3CLpro (in silico) & Jo et al., 2020 \\
\hline \multirow[t]{2}{*}{ Galangin } & $\begin{array}{l}\text { Herpes simplex virus type } 1 \\
\text { (HSV-1) }\end{array}$ & High antiviral activity & $\begin{array}{l}\text { Mayer et al., } \\
1997\end{array}$ \\
\hline & $\begin{array}{l}\text { Coxsackie B virus type } 1 \\
\text { (Cox B1) }\end{array}$ & High antiviral activity & \\
\hline
\end{tabular}

\section{Acknowledgement}

This work is to support the application of those plants as nutraceuticals product under program of Research Grant for Higher Education Applied Research ["Penelitian Terapan Unggulan Perguruan Tinggi"] 2020 from The Ministry of Research and Technology, Indonesia awarded to EM.

\section{References}

Ahlina, F.N., Nugraheni, N., Salsabila, I.A., Haryanti, S., Da'i, M., Meiyanto, E. (2020). Revealing the reversal effect of galangal (Alpinia galanga L.) extract against oxidative stress in metastatic breast cancer cells and normal fibroblast cells intended as a co-chemotherapeutic and antiageing agent. Asian Pacific Journal of Cancer Prevention, 21(1): 107-117. DOI: 10.31557/APJCP.2020.21.1.107 
Chan, J.F., Kok, K., Zhu, Z., Chu, H., To, K.K., Yuan, S., Yuen, K. (2020). Genomic characterization of the 2019 novel human-pathogenic coronavirus isolated from a patient with atypical pneumonia after visiting Wuhan. Emerging Microbes \& Infections, 9(1): 221-236. DOI: 10.1080/22221751.2020.1719902

Chang, Y., Tung, Y., Lee, K., Chen, T., Hsiao, Y., Chang, H., Hsieh, T., Su, C., Wang, S., Yu, J., Shih, S., Lin, Yu-Hsiang, Lin, Yin-Hung, Tu, Y.E, Tung, C., Chen, C. (2020). Potential therapeutic agents for COVID-19 based on the analysis of protease and RNA polymerase docking. Preprints. DOI: 10.20944/preprints202002.0242.v1

Chen, H. \& Du, Q. (2020). Potential natural compounds for preventing 2019-nCoV infection. Preprints, 2020: 202001.0358.v1.

Dong, W., Wei, X., Zhang, F., Hao, J., Huang, J., Zhang, C., Liang, W. (2014). A dual character of flavonoids in influenza $A$ virus replication and spread through modulating cell-autonomous immunity by MAPK signaling pathways. Scientific Reports, 4: 7237. DOI: 10.1038/srep07237

Frabasile, S., Koishi, A.C., Kuczera, D., Sliveira, G.F., Verri Jr., W.A., dos Santos, C.N.D., Bordignon, J. (2017). The citrus flavanone naringenin impairs dengue virus replication in human cells. Scientific Reports, 7: 41864. DOI: 10.1038/srep41864

Haider, Z., Subhani, M.M., Farooq, M.A., Ishaq, M., Khalid, M., Khan, R.S.A., Niazi, A.K. (2020). In silico discovery of novel inhibitors against main protease (Mpro0 of SARS-CoV-2 using pharmaciphore and molecular docking based virtual screening from ZINC database. Preprints. DOI: 10.20944/preprints202002.0431.v1

Harrison, C. (2020). Coronavirus puts drug repurposing on the fast track. Nature Biotechnology. DOI: 10.1038/d41587-020-00003-1

Hu, Z., Hu, J., Ren, F., Xu, H., Tan, M., Wang, Q, Ren, J. (2020). Nobiletin, a novel inhibitor, inhibits HBsAg production and hepatitis B virus replication. Biochemical and Biophysical Research Communications, 523: 802-808. DOI: 10.1016/j.bbrc.2019.12.099

Jo, S., Kim, S., Hhin, D.H., Kim, M. (2020). Inhibition of SARS-CoV 3CL protease by flavonoids. Journal of Enzyme Inhibition and Medicinal Chemistry, 35(1): 145-151. DOI: 10.1080/14756366.2019.1690480

Li, G. \& De Clercq, E. (2020). Therapeutic options for the 2019 novel coronavirus (2019-nCoV). Nature Reviews Drug Discovery, 19: 149-150. DOI: 10.1038/d41573-020-00016-0

Lin, C., Tsai, F., Tsai, C., Lai, C., Wan, L., Ho, T., Hsieh, C., Chao, P.L. (2005). Anti-SARS coronavirus $3 \mathrm{C}$-like protease effects of Isaris indigotica root and plant-derived phenolic compounds. Antiviral Research, 68: 36-42. DOI: 10.1016/j.antiviral.2005.07.002

Lin, S., Chen, M., Li, S., Lin, C., Wang, T.W. (2017). Antiviral activity of nobiletin against chikungunya virus in vitro. Antiviral Therapy, 22: 689-697. DOI: 0.3851/IMP3167

Meiyanto, E. \& Larasati, Y. (2019). The chemopreventive activity of Indonesia medicinal plants targeting on hallmarks of cancer. Advanced Pharmaceutical Bulletin, 9(2): 219-230. DOI: 10.15171/apb.2019.025

Meyer, J.J.M., Afoloyan, A.J., Taylor, M.B., Erasmus, D. (1997). Antiviral activity of galangin isolated from the aerial parts of Helichrysum aureonitens. Journal of Ethnopharmacology, 56: 165-169.

Nogata, Y., Sakamoto, K., Shiratsuchi, H., Ishii, T., Yano, M., Ohta, H. (2006). Flavonoid composition of fruit tissues of citrus species. Bioscience Biotechnology \& Biochemistry, 70(1): 178-192. DOI: 10.1271/bbb.70.178

Peng C., Zhu, Z., Shi, Y., Wang, X., Mu, K., Yang, Y., Zhang, X., Xu, Z., Zhu, W. (2020). Exploring the binding mechanism and accessible angle of SARS-CoV-2 spike and ACE2 by molecular dynamics simulation and free energy calculation, ChemRxiv. DOI: 10.26434/chemrxiv.11877492.v1

Qamar, M.T., Alqahtani, S.M., Alamri, M.A., Chen, L. (2020). Structural basis of SARS-CoV-2 3CL pro and anti-COVID-19 drug discovery from medicinal plants. Preprints. DOI: 10.20944/preprints202002.0193.v1 
Roser, M. \& Ritchie, H. (2020). Coronavirus Disease (COVID-19). Published online at OurWorldInData.org. Retrieved from: 'https://ourworldindata.org/coronavirus' [Online Resource]

Saha, R.K., Takahashi, T., Suzuki, T. (2009). Glucosyl hesperidin prevents influenza A virus replication in vitro by inhibition of viral sialidase. Biological and Pharmaceutical Bulletin, 32(7): 1188-1192.

Salehi, B., Fokou, P.V.T., Sharifi-Rad, M., Zucca, P., Pezzani, R., Martins, N., Sharifi-Rad, J. (2019). The therapeutic potencial of naringenin: a review of clinical trials. Pharmaceuticals, 12:11. DOI: 10.3390/ph12010011

Senathilake, K.S., Samarakoon, S.R., Tennekoon, K.H. (2020). Virtual screening of inhibitors against spike glycoprotein of 2019 novel corona virus: a drug repurposing approach. Preprints. DOI: 10.20944/preprints202003.0042.v1

Smith, M. \& Smith, J.C. (2020). Repurposing therapeutics for COVID-19: supercomputer-based docking to the SARS-CoV-2 viral spike protein and viral spike protein-human ACE2 interface. ChemRxiv. DOI: 10.26434/chemrxiv.11871402.v3

Tang, K., He, S., Zhang, X., Guo, J., Chen, Q., Yang, F., Banadyga, L., Zhu, W., Qiu, X., Guo, Y. (2018). Tangeretin, an extract from Citrus peels, blocks cellular entry of arenaviruses that cause viral hemorrhagic fever, Antiviral Research, 160: 87-93. DOI: 10.1016/j.antiviral.2018.10.011

Wan, Y., Shang, J., Graham, R., Baric, R.S., Li, F. (2020). Receptor recognition by novel coronavirus from Wuhan: an analysis based on decade-long structures studies of SARS. Journal of Virology. DOI: 10.1128/JVI.00127-20

Wang, J. (2020). Fast identification of possible drug treatment of coronavirus disease-19 (COVID-19) through computational drug repurposing study, ChemRxiv. DOI: 10.26434/chemrxiv.11875446.v1

Wrapp, D., Wang, N., Corbett, K.S., Goldsmith, J.A., Hsieh, C., Abiona, O., Graham, B.S., McLellan, J.S. (2020). Cryo-EM structure of the 2019-nCoV spike in the prefusion conformation. Science. DOI: $10.1126 /$ science.abb2507

Xia, S., Zhu, Y., Liu, M., Lan, Q., Xu, W., Wu, Y., Ying, T., Liu, S., Shi, Z., Jiang, S., Lu, L. (2020). Fusion mechanism of 2019-nCoV and fusion inhibitors targeting HR1 domain in spike protein, Cellular \& Molecular Immunology. DOI: 10.1038/s41423-020-0374-2

Xu, H., Zhong, L., Deng, J., Peng, J., Dan, H., Zeng, X., Li, T., Chen, Q. (2020a). High expression of ACE2 receptor of 2019-nCoV on the epithelial cells of oral mucosa. International Journal of Oral Science, 12: 8. DOI: 10.1038/s41368-020-0074-x

Xu, J., Liu, Z., Tang, W., Wang, G., Chung, H.Y., Liu, Q., Zhuang, L., Li, M., Li, Y. (2015). Tangeretin from Citrus reticulate inhibits respiratory syncytial virus replication and associated inflammation in vivo. Journal of Agricultural and Food Chemistry, 63: 9250-9257. DOI: 10.1021/acs.jafc.5b03482

Xu, X., Chen, P., Wang, J., Feng, J., Zhou, H., Li, X., Zhong, W., Hao, P., 2020b. Evolution of the novel coronavirus from the ongoing Wuhan outbreak and modeling of its spike protein for risk of human transmission. Sci. China Life Sci. 63, 457-460.

Yan, R., Zhang, Y., Li, Y., Xia, L., Guo, Y., Zhou, Q. (2020). Structural basis for the recognition of the SARS-CoV-2 by full-length human ACE2. Science. DOI: 10.1126/science.abb2762

Zhang, H., Penninger, J.M., Li, Y., Zhong, N., Slutsky, A.S. (2020). Angiotensin-converting enzyme 2 (ACE2) as a SARS-CoV-2 receptor: molecular mechanisms and potential therapeutic target. Intensive Care Medicine. DOI: 10.1007/s00134-020-05985-9

Zhavoronkov, A., Aladinskiy, V., Zhebrak, A., Zagribelnyy, B., Terentiev, V., Bezrukov, D.S., Polykovskiy, D., Shayakhmetov, R., Filimonov, A., Orekhov, P., Yan, Y., Popova, O., Vanhaelen, Q., Aliper, A., Ivanenkov, Y. (2020). Potential COVID-2019 3C-like protease inhibitors designed using generative deep learning approaches. ChemRxiv. DOI: 10.26434/chemrxiv.11829102.v2

Zumla, A., Chan, J.F.W., Azhar, E.I., Hui, D.S.C., Yuen, K. (2016). Coronaviruses - drug discovery and therapeutic options. Nature Reviews Drug Discovery, 15: 327-347. DOI: 10.1038/nrd.2015.37 